\title{
Experience's Potential and Potential Experiences: Subjectivity, Alterity, and Futurity in the Late- Apartheid Novels of Nadine Gordimer
}

\section{Peter Blair}

\section{CpenEdition}

\section{Journals}

Electronic version

URL: https://journals.openedition.org/ces/439

DOI: $10.4000 /$ ces. 439

ISSN: 2534-6695

\section{Publisher}

SEPC (Société d'études des pays du Commonwealth)

\section{Printed version}

Date of publication: 10 June 2019

Number of pages: 103-115

ISSN: 2270-0633

\section{Electronic reference}

Peter Blair, "Experience's Potential and Potential Experiences: Subjectivity, Alterity, and Futurity in the Late-Apartheid Novels of Nadine Gordimer", Commonwealth Essays and Studies [Online], 41.2| 2019, Online since 05 November 2019, connection on 16 July 2021. URL: http://journals.openedition.org/ ces/439 ; DOI: https://doi.org/10.4000/ces.439

\section{(c) $($ ) $(3)$}

Commonwealth Essays and Studies is licensed under a Licence Creative Commons Attribution - Pas d'Utilisation Commerciale - Pas de Modification 4.0 International. 


\section{Experience's Potential and Potential Experiences: Subjectivity, Alterity, and Futurity in the Late-Apartheid Novels of Nadine Gordimer}

This article begins by scrutinizing divergent critical views of Gordimer's subject position and authorial agency, which locate her variously on a spectrum ranging from liberalhumanist autonomy to historical-materialist determinism. It then considers how Gordimer's nonfiction articulates a parallel ambivalence about the reach of the writer's imagination (and its dependence on "the potential of his own experience"), particularly regarding the ethics and feasibility of creating racially "other" characters. Its main part reads July's People (1981), in relation to other Gordimer novels, as a similarly self-reflexive engagement with subjectivity and alterity: the otherness of the imagined future (a "potential experience") facilitates fresh sociopolitical perspectives, even as the novel expresses philosophical scepticism about such imaginative extrapolation and its textual representation. The article concludes with a new reading of the novel's "open" ending as a projection of this epistemological conflict.

\section{Subjectivity: Gordimer's Late-Apartheid Critics}

By place I don't mean a predetermined place $[\ldots]$. You are consciously or unconsciously creating a position in your society. (Gordimer, in Gray 180)

Amongst the proliferation of literary criticism on Gordimer produced between the publication of July's People (1981) and South Africa's transition to democracy (1994) are two major books that offer contrasting conceptions of Gordimer's subject position and authorial agency: Stephen Clingman's benchmark The Novels of Nadine Gordimer: History from the Inside (1986), which elucidates the linear development of Gordimer from "liberal" to "radical," hinging on The Late Bourgeois World (1966); and Kathrin Wagner's iconoclastic Rereading Nadine Gordimer (1994), which refutes this historical linearity. Clingman reads Gordimer's novels as articulating a "history from the inside" in the dual sense that Gordimer is writing from the midst of the history she is describing even as it shapes her inner consciousness (and those of her historically embedded protagonists): "At the same time as she engages with history she is moulded by the patterns and forces she must try to assess" (2). He gives Gordimer much credit, both for the sensitivity with which she registers the nuances of her times and for her unrelentingly tough examination of her own relation to these times; Gordimer, he points out, "has never let up on herself ideologically" (26). In this view, Gordimer, like Helen Shaw at the end of The Lying Days (1953) - the autobiographical Bildungsroman with which Gordimer made her novelistic debut - has at every stage been resolved to accept "disillusion as a beginning rather than an end" (367). Nevertheless, Clingman acknowledges that Gordimer's "history from the inside" is "not only privileged but also confined by its 'inside' position" (2). Gordimer's perspective, he argues, is doubly limited, socially and temporally, by her "split position" (206) as a dissident yet privileged white in apartheid South Africa: her novels are implicitly addressed to black South Africans and to a post-revolutionary future, from both of which she was cut off by apartheid.

This liberal-radical teleology, which necessarily deferred much to a third, liberated phase, was subsequently nuanced by Judie Newman's concise chronological study 
(1988), which foregrounded the "conditioning factor $[\ldots]$ of gender" and "the relation of genre to gender" (17). But the pre-eminence of racial politics as an interpretive framework had already been problematized by John Cooke's monograph The Novels of Nadine Gordimer: Private Lives/Public Landscapes (1985), which considered Gordimer's "major theme" to be "the liberation of children from unusually possessive mothers" (10) and her secondary concern its intertwining with the liberation of black South Africans from the repressive state. This wasn't quite "history from the outside," but it did de-privilege history by re-casting the "public" as an adjunct to the "private." With postapartheid hindsight, Michael Chapman (1996) similarly asserted that "[i]t is debatable whether Gordimer has produced many political novels that are not, at core, something more domestic: Freudian family romances" (235); and, reviewing Gordimer's career after her death in 2014, Jeanne-Marie Jackson (2015) even suggested that "we might read Gordimer's oeuvre as a single Bildungsroman that unfolds its own inversion; in other words, a coming-of-age narrative that results in individual sublimation or undoing" (55).

Like Clingman, however, Wagner privileges the category of "history," but considers the novels to be more fundamentally limited - and, indeed, seriously flawed - by Gordimer's subject position, and by Gordimer's own underestimation of its constraints. Wagner argues that Gordimer's "necessary entrapment in both class and historical moment in South Africa makes her unavoidably vulnerable to the unconscious inscription of its stereotypes and clichés" (70). While acknowledging Gordimer's ideological vigilance, she distinguishes between Gordimer's narrow conception of ideology as "the clearly articulated programmes of particular groups with specific social, political and economic agendas" (29), which reflect "overt cognitive structures," and the "covert emotional structures" that often conflict with these at the level of the text (225; cf. v). Gordimer's novels, Wagner argues, at a subtextual level more often than not confirm the apartheid orthodoxy they strive to confront, and ultimately succumb to the white repressions they are at pains to confess:

Much of the fiction can be read as paradoxically confirming the deepest nightmares of the beleaguered white imagination, and as supporting at a subtextual level precisely those conservative fears and prejudices which oppose change, and which the surface rhetoric of the texts implicitly challenges. (47)

While the "gradual politicisation" in response to an evolving regime (on which Clingman focuses) is registered at the surface level of the text, Wagner thus emphasizes "extraordinary continuities of perspective" informing Gordimer's deepest responses to "the essentially unchanging immoral framework of apartheid" (164; cf. 41). Clingman's understating of these continuities Wagner attributes to what she considers his failure to problematize the general concept of "history" (235n), and especially to his underestimation of the subjective nature of Gordimer's particular version of South African history - a version which Wagner regards as over-expository in extent while sketchy and clichéd in content, and as therefore explaining the lack of domestic enthusiasm for Gordimer's work relative to her lionization abroad $(8,33,56)$. This hermeneutic contrast is reflected in the ways in which the studies are structured, for whereas Clingman's chapters are chronological, Wagner's are thematic. Thus while for Clingman Gordimer's fiction is expressive of a developing perspective from an evolving subject position, for Wagner it is fundamentally predetermined by an essentially fixed position, every attempt to tran- 
scend which results in its (often unconscious) codified transcription. Where Clingman sees modulation and progression, Wagner sees permutation and proliferation.

Perhaps the most significant feature of Wagner's analysis is the inevitability she detects in Gordimer's writing (Gordimer's historical "entrapment" making her "unavoidably" predisposed to stereotypes), which contrasts markedly with the constrained agency that Clingman diagnoses. On the one hand (Clingman), subjectivity is considered essentially active, operating like a verb - what is seen and described is the subject of, constituted by, and understood in relation to, the writer; on the other hand (Wagner), subjectivity is deemed fundamentally passive, functioning as a noun - what is seen and described is subject to, constituted of, and understood as relative to, the writer. This bifurcation reflects contrasting conceptions of writing: on the first view, a heuristic process undertaken from an evolving position; on the second, a predestined product of an essentially static position. In essence, whereas Clingman reads Gordimer's fiction as strongly influenced, but not determined, by her privileged position as a white in apartheid society, Wagner reads Gordimer's fiction as wholly determined by this position. While Clingman's reading could thus be considered a nuanced iteration of the once-popular image of Gordimer as apartheid South Africa's conscience, Wagner's reading reduces Gordimer to something for which apartheid is responsible.

Of the post-apartheid books devoted to Gordimer's apartheid-era fiction, perhaps most notable is Ileana Dimitriu's Art of Conscience (2000), a revisionist "counterchronological' reading" (27) animated by a "revindicated humanism" (18) that "permit[s] Gordimer a greater command of her own story and her own autonomy than Clingman [or] Wagner" (17). While it might be argued that Gordimer is less autonomous than Dimitriu suggests, and her failings greater than Clingman allows but lesser than Wagner insists, what interests me here is that the tensions between these readings, which seek to locate Gordimer on a spectrum ranging from liberal-humanist autonomy to historical-materialist determinism, mirror Gordimer's own engagement with her subject position over the preceding decades, an engagement apparent in her ambivalence about the reach of the writer's imagination.

\title{
Subjectivity and Alterity: Gordimer's Nonfiction
}

\begin{abstract}
"How could it be true, that which both of us knew - that he was me, and I was him? [...] how could I recognize my situation in his?" (Gordimer, A World of Strangers 252)

"Exploitation, which the blacks experience as their reality, [...] the white artist [...] experiences [...] through a moral attitude or a rational empathy." (Gordimer, "Relevance" 139, author's emphasis)
\end{abstract}

In her "Introduction" to No Place Like: Selected Stories (1975), Gordimer expressed an enduring belief that the writer is gifted with "[p] owers of observation heightened beyond the normal" (12): for her, the writer is cognitively androgynous (a belief with which her feminist critics take issue) and imaginatively promiscuous, a "strange creature who can get into the skin of all sexes, all ages" (Marchant, Kitchen, and Rubin 261) and move "deep under the surface of human lives" by virtue of having "at least some faculties of supra-observation and hyperperception not known to others" ("Living" 277). Nevertheless, Gordimer has always been aware of the limits to empathetic perception that inhere in every human relationship, however close. For example, in a moving essay written in memory of the black writer Nat Nakasa (a close friend who left South Africa 
on an exit permit to study at Harvard, and in 1965 committed suicide), Gordimer writes with a consciousness of the limits of empathy at the forefront of her mind:

So do the limits of human relationships constantly fling us back; so do one's hands fall, helpless, before the quintessential loneliness of each human being. It is keeping this in mind that I write of him, respecting the ultimate despair that took him beyond the understanding of friends, aware that what each of us knows of him was only part of what he was, and lived, and suffered, and that even when we have put it all together there will always be something - perhaps the unbearable sum of the total in itself? - that he kept to himself and died of. ("One Man" 80)

The contrast between this reverential helplessness before the limits of empathy and the audacious disdain of the creative artist for such limits, points up a suggestive ambiguity in Gordimer's descriptions of the writer's peculiar "powers of observation": in what sense are these powers "beyond" the normal? On the one hand, Gordimer seems to be describing the writer as differing from her fellow human beings only in terms of the degree to which she has developed a common faculty of observation: her "powers of observation" are "heightened beyond the normal" (emphasis added). On the other hand, these "powers of observation" derive from a faculty essentially different from "the normal": Gordimer seems to be describing the writer as a breed apart, a specially evolved "strange creature," "looking pretty much like other human beings" but possessed of - even possessed by - "faculties of supra-observation and hyperperception not known to others" ("Living" 277). Acknowledgement that the writer shares a universal human limitation is set aside, and she asserts differences of degree and kind.

As is implicit in Gordimer's elegy for Nakasa, this ambivalence about the nature, and consequently the reach, of the empathetic imagination was increased by apartheid. As Wagner points out, Gordimer's

characteristically humanist belief in that fundamental brotherhood of man which allows the artist to enter imaginatively into the life of the other, regardless of gender, creed or colour, quickly found itself at odds with the political argument that, within the specific contexts of the resistance struggle, such an appropriation of the experience of the "Other" was unacceptably arrogant. (116)

Just as Africanists within the ANC, and advocates of the Black Consciousness that emerged from the late 1960s, felt it patronizing for liberal whites to represent (speak on behalf of) blacks politically, so it was felt by many that it was inappropriate, even exploitative, for white writers to represent (portray) black characters. At the same time, failing to engage with black politics or excluding black characters was arguably complicit with apartheid. Gordimer thus found herself in an invidious double-bind familiar to white South African liberal activists and writers alike. In her political nonfiction, this is acutely reflected in a statement - which Clingman justly describes as one of "extraordinary vulnerability and toughness" ("Introduction" 7) - towards the end of her 1979 address on "Relevance and Commitment":

Although I am white and fully aware that my consciousness inevitably has the same tint as my face, when I have spoken of white attitudes and opinions I have not taken it upon myself to speak for whites, but have quoted attitudes and opinions expressed by whites themselves, or manifest (in my opinion) in their work. When I have spoken of black attitudes and opinions, I have not taken it upon myself to speak for blacks, but have quoted attitudes and opinions expressed by blacks themselves or (in my opinion) manifest in their work. (143) 
Her essays and interviews (and, of course, her interviewers) are preoccupied with the related issue of whether it is politically appropriate to create black characters in fiction, but also with the question of whether she is imaginatively able to do it credibly. In her 1961 essay "The Novel and the Nation in South Africa" Gordimer considered that "there is little reason why a straightforward novel of events in which the protagonists are black men should not be written just as authentically by a white writer as by a black one" (44). However, with the entrenchment of apartheid and the rise of Black Consciousness, she becomes less sure, and in a 1972 note appended to the essay considered that "changes in South Africa since 1961" have so restricted blacks' and whites' experiences of each other, and so widened the gulf between separate black experience and white experience, as to restrict the areas of black life about which white authors are capable of writing:

[...] I now believe that George Lukács is right when he says that a writer, in imaginative creation and the intuition that comes with it, cannot go beyond the potential of his own experience. That potential is very wide; but living in a society that has been as deeply and calculatedly compartmentalized as South Africa's has been under the colour bar, the writer's potential has unscalable limitations. There are some aspects of a black man's life that have been put impossibly beyond the white man's potential experience, and the same applies to the black man and some aspects of a white man's experience. Both can write of the considerable fringe society in which black and white are "known," in a meaningful sense, to one another; but there are areas from which, by iron circumstance, each in turn finds himself shut out, even intuitively, to their mutual loss as writers. (52, author's emphases)

In an interview of the same year Gordimer similarly conceded:

there are some areas of life white writers can't enter into, even given the intuitive and imaginative powers that writers have. [...] when there are certain experiences that are outside your potential, that are inconceivable and could never happen to you, then your subject matter is restricted to some extent; and it's restricted in this country with its colour bar more than in any other. (Gray and Du Plessis 63)

Nevertheless, despite these qualifications of her imaginative precocity, Gordimer continued doggedly to insist on the existence and importance of the "considerable fringe society in which black and white are 'known,' in a meaningful sense, to one another": in 1962 she says that she has usually written "about the borderland, the kind of frontier where black and white do meet" (Terkel 16, author's emphasis); in 1980 she similarly insists on the literary viability for the white writer of "vast areas of actual experience rubbing shoulders with blacks, having all kinds of relationships with blacks" (Gardner 168); and in 1982 she declares that when she has written black characters - "dared to do it from a black point of view," as she tellingly puts it - it "has always been within my orbit of experience, my close experience of blacks" (Boyers et al. 211; cf. Bazin and Seymour 222, 245).

However, Gordimer's assertion of the validating power of experience is problematized by an ambiguity in her description of that experience's "potential." This ambiguity is evident in her two-fold description of the limitation of the white writer who "cannot go beyond the potential of his own experience" from which is missing "aspects of a black man's life [...] impossibly beyond the white man's potential experience," and latent in her description of "certain experiences that are outside your potential, that are inconceivable and could never happen to you": the difference is between one's 
potential experience (experiences that one possibly could have in the future, positions into which one could imagine oneself being placed) and the potential of one's own experience (the potential contained within one's past experiences for imaginative extrapolation, including projection into positions in which one cannot conceive of being placed). This equivocal notion of experience's potential is indicative of the dual nature of Gordimer's understanding of subjectivity, for the conception of the "other" in terms of one's own and one's potential experiences implies a relatively passive subjectivity, whereas the conception of the "other" by extrapolating from one's own experiences by virtue of their innate potential implies a more active subjectivity. (This active extrapolation is, indeed, crucial to Gordimer's definition of fiction as "a way of exploring possibilities present but undreamt of in the living of a single life" ["Introduction" 12].) Just as Gordimer's notion of the perceptual mode by which experience is constituted was equivocal, so too is her notion of the potential residing in the experience so constituted. Both equivocations would be exposed by Gordimer's imagining of a future revolution.

\title{
Subjectivity, Alterity, Futurity: July's People and "The Transport of a Novel”
}

\author{
There is, it seems to us, \\ At best, only a limited value \\ In the knowledge derived from experience. \\ The knowledge imposes a pattern, and falsifies, \\ For the pattern is new in every moment \\ And every moment is a new and shocking \\ Valuation of all we have been. \\ (T.S. Eliot, "East Coker" 199)
}

"How was she to have known, until she came here [...]" (Gordimer, July's People 98)

In July's People (1981), Gordimer's conflicting conceptions of the reach of the writer's imagination (hyperperceptive or limited), and of her experience's potential (contained in or contained by the writer's personal experience), are put under particular pressure by their application not just to alterity but also to futurity, an additional and analogous problem of subjective representation that is also posited as a solution to the problem of alterity. Set during a projected black uprising - a "potential experience" which, since the 1976 Soweto revolt, was felt to be imminent -July's People tells the story of the white Smales family who flee their Johannesburg suburb and take refuge in the rural village of their black servant, a migrant worker they call July, whose real name is Mwawate. In this space-time shift, the othernesses of the imagined future and the impoverished village present challenges that yield fresh socio-political perspectives (on the family's privileged past, and on their former employee), even as the novel expresses philosophical scepticism about such imaginative extrapolation and its textual representation.

While Gordimer's apartheid-era novels were predominantly set in the near-contemporary past, they were implicitly - and, increasingly, explicitly - future-orientated, being predicated on revolution. As a speculative fiction set during the predicted revolution, July's People extends and reifies this teleology. Nevertheless, the novel refuses to imagine the revolution itself and its inevitable violence, which are sketchily evoked by radio reports and ambiguously embodied in the helicopter that descends in the final chapter. 
The novel is also limited in its refusal to imagine what might come after the revolution, remaining stalled in the "interregnum" adumbrated by its epigraph from Antonio Gramsci's Prison Notebooks: "The old is dying and the new cannot be born; in this interregnum there arises a great diversity of morbid symptoms." Gordimer would subsequently extend the term "interregnum" backwards from its endgame to encompass the whole protracted period between the Soweto uprising and the expected post-apartheid settlement ("Living"). In terms of futurity, A Sport of Nature (1987), a later Gordimer novel that ranges from the 1950s to the projected inauguration of a liberated South Africa, is marginally more daring than July's People. Only A Guest of Honour (1970), an earlier novel, projects a nascent postcolonial polity and post-independence strife, though its setting in a composite central African state, and one that has very recently been a British colony rather than an internally colonized settler republic, complicates its implications for South Africa. Gordimer is thus cautious in imagining South Africa's revolutionary and post-revolutionary destiny, and July's People turns back from these ineffable limits and inverts its own forward-looking linearity. As Clingman noted, "what appears to be a projection from the present into the future in the novel is from another point of view seeing the present through the eyes of the future" (201-2, author's emphasis); and as Nicholas Visser put it, "the projected revolutionary moment carries a powerful defamiliarizing effect, laying bare the underlying social and material conditions of the earlier, prerevolutionary, way of life" ("The Politics" 70). July's People is thus both speculative and peculiarly retrospective - a "future history," which Michael Green defined as "works which seek to comment upon the past and present by projecting the implications of the past and the present forward in time" (14).

This temporal manoeuvre is also a spatial one, most fully explored by Rita Barnard: "a defamiliarization - effected in Gordimer's novel through a geographical displacement $-[\ldots]$ allows one to see the quotidian practice of class society as unnatural and unjust" (57). The displacement is thus intra-national (from urban to rural) and across the nation's racialized class stratifications (from affluence to poverty), but it might also be deemed transnational in the illegitimate terms of the Bantustan policy that sought to exclude black "homelands" from the white state (and so exacerbates the split identity of July/Mwawate), as well as in the temporal sense that the projected South Africa is on the cusp of becoming another country. Transnational displacements afford new perspectives on South African society in other Gordimer novels: the thought experiments of $A$ Guest of Honour and $A$ Sport of Nature (which travels to various parts of Africa and Europe); Burger's Daughter (1979), in which Rosa Burger returns to the post-Soweto struggle from a sojourn in France; and The Pickup (2001), in which Julie Summers emigrates from post-apartheid South Africa to an unnamed Middle Eastern country. Though the transnationalism of July's People is problematic and provisional, in all five novels new transnational perspectives entail the re-imagining of black characters as agents rather than subalterns.

In July's People, as Visser's and Barnard's comments indicate, the defamiliarizing space-time shift enables a devastating critique of contemporary consumer capitalism and liberal humanism. Maureen Smales's "belief in the absolute nature of intimate relationships between human beings" (64) is displaced by a recognition of the determining power of "place in the economy" (65). Objects are divested of their former meanings and assume new significances, and subjectivities contingent on material possessions 
collapse when dispossessed, exemplified by the disintegration of Bamford Smales, who derived his alpha-male identity from his gun and baakie (as suggested by his forename, an amalgam of "bam" and "Ford"; and by his surname's sibilant prefixing of "males," which facilitates a diminishing play on "small," "smalls," and "snails," and suffixed to his forename suggests that he is more broadly representative of such hollow masculinity: "bamFord's males"). The Enlightenment ideal of equality between human beings who are essentially free of social determinants, and therefore capable of dispassionate observation, is thus undermined. White South African liberalism is exposed as a particularly deluded and complicit instance of the ideal, and as incompatible with the Black Consciousness philosophy of self-esteem and self-liberation that provides an essential intellectual context despite not being named in the novel (Powell).

This critique is enabled by July's People's subversion of three major literary genres: the castaway novel (Titlestad and Kissack), especially Robinson Crusoe (1719; see Medalie); the imperial romance (Greenstein); and "the Countryman-Comes-to-Town theme," which Gordimer lists as one of "five main [...] themes" in African literature (The Black Interpreters 33). In particular, July's People inverts the white liberal paternalist version of "the Countryman-Comes-to-Town theme," the so-called "Jim-Comes-to-Jo'burg" narratives epitomised by Alan Paton's Cry, the Beloved Country (1948). Gordimer's inversion, in which a black migrant "Jim" challenged by city life is replaced by urban white refugees confounded by the countryside, is foreshadowed by The Conservationist (1974), in which Johannesburg mining-magnate Mehring has his complacent proprietorship of a highveld hobby-farm undermined by the discovery there of a black corpse that refuses to stay buried.

As well as these intertextual revisions, July's People poses more fundamental questions about books, particularly regarding the relevance of fiction and the reliability and efficacy of nonfiction. For Sonny, the bibliophile revolutionary of My Son's Story (1990), which appeared almost a decade later, books are a "source of transcendence - a way out of battered classrooms, the press of Saturday people, the promiscuity of thin-walled houses, and at the same time back into them again with a deeper sense of what the life in them might mean" (17). For Maureen, however, such "transcendence" - and hence enlightened re-entry - has become impossible. One of the possessions brought along as the family flee is Alessandro Manzoni's classic historical novel I Promessi Sposi (1827), "in translation as The Betrothed" (28):

But the transport of a novel, the false awareness of being within another time, place and life that was the pleasure of reading, for her, was not possible. She was in another time, place, consciousness; it pressed in upon her and filled her as someone's breath fills a balloon's shape. She was already not what she was. No fiction could compete with what she was finding she did not know, could not have imagined or discovered through imagination. (29, author's emphasis)

A later attempt to achieve "transcendence," the imaginative "transport" of immersive reading offered by the literal "transport" of the material book, is similarly stymied by Maureen's new context: "she sat outside the hut and could not understand I Promessi Sposi. It was translated from the Italian but would not translate from the page to the kind of comprehension she was able to provide now" (138-9). Manzoni's "account of bread riots in Milan in 1628" begs analogy with the present black South African revolt, but in Maureen merely produces "an olfactory impression of bread" that recalls from 
her childhood her black nanny Lydia's indifferent baking (139). Manzoni’s novel, and perhaps by extension all novels, seems as obsolete and irrelevant as the passbook that July is similarly reluctant to discard (137).

More obviously relevant is a work of documentary non-fiction specifically about South Africa, containing a photograph of Maureen's childhood self with Lydia, which Maureen recollects a few pages after first attempting Manzoni's novel:

Years later someone showed it to Maureen Smales in a Life coffee-table book about the country and its policies. White herrenvolk attitudes and life-styles; the marvellous photograph of the white schoolgirl and the black woman with the girl's school case on her head.

Why had Lydia carried her case?

Did the photographer know what he saw, when they crossed the road like that, together? Did the book, placing the pair in its context, give the reason she and Lydia, in their affection and ignorance, didn't know? (33)

Gordimer's second novel, A World of Strangers (1958), had expressed dissatisfaction with similar, often overseas, representations of South Africa. Englishman Toby Hood arrives in Johannesburg to work as a publisher's agent, measuring his experience of the place against "all those books about Africa [he] had been reading [...]. The bluebooks, the leaflets, the surveys, the studies - the thick ones by economists and agronomists, the sensational ones by journalists" (18); but, as Stefan Helgesson notes of this novel in which "the theme of print versus place is remarkably pronounced" (110), ultimately "history disallows a retreat from the symbolic realm of print," which "stages a comeback" in the final chapter (113) in the form of "two newspaper cuttings; and a letter" the departing Hood carries in his pocket ( $A$ World 265). July's People would similarly seem to reassert the power of print, for though Maureen's contemplation of Life's interpretation of the photograph ends with three questions, these are ultimately rhetorical as she is "forced to relinquish 'her role as observer and composer of the frame' [...], and she must recognize her inability to read the visual narrative of July's village" (Wright 87).

The questions, however, are less about the adequacy of print to capture - and intervene in - the experienced place than about the limitations of experience itself, making July's People “Gordimer's most radical renunciation of the knowledge yielded by observation" (Cooke 168). When July's wife grumbles that it was unnecessary for the burdensome white refugees to flee the city she has never visited, and the killing she hasn't witnessed, July counters: "You can't imagine those houses. [...] Unless you've been there, you can't understand how it is" (19); but the Life photograph encapsulates the more extreme point that even being "there" - perhaps anywhere - is not enough to enable understanding, and may in fact hamper understanding of broader "context." This is demonstrated by the retrospective revelation not just of what Maureen "did not know" but also, crucially, what she "could not have imagined or discovered through imagination" (emphasis added). The revolution's "explosion of roles" (117) that prompts her to re-think her childhood relationship with Lydia also forces her into a new understanding of her adult master-servant relationship with July, an understanding that would not otherwise have been possible: "How was she to have known, until she came here, that the special consideration she had shown for his dignity as a man, while he was by definition a servant, would become his humiliation itself [...]" (98, emphasis added). While Wright and Cooke are thus correct in affirming that the novel exposes the interestedness and unreliability of observation, what is striking is that the means by which July's wife might 
"understand" and Maureen might have "discovered" or "known" things about others' lives is imagination, and that imagination is shown to be contingent on experience. In the terms Gordimer deploys in the nonfiction discussed above, Maureen's pre-revolution "experience" was so role-bound that it lacked the "potential" for her to understand July; the spatial and temporal displacement of revolution (a "potential experience" that Gordimer's speculative fiction makes come to pass) gives Maureen a new experience - "an experience that couldn't be forethought" (127) - that has the "potential" she formerly lacked. Futurity is required to enable Maureen's retrospective understanding of alterity, reflecting a conception of subjectivity in which epistemology is firmly grounded in ontology.

But if July's People thus seems to articulate Gordimer's bleakest view of subjectivity - as a materially, temporally, and spatially contingent false consciousness - this is resisted by the very form in which it is articulated, which suggests a more sanguine view: just as $A$ World of Strangers was itself a textual representation of the kind about which it expressed reservations, Maureen is herself an imagined character in a novel of the kind that she finds redundant - the kind that does allow discovery through imagination, not least, paradoxically, those things which Maureen is shown as able to discover only through the hindsight acquired by bitter experience. Maureen's new "experience that couldn't be forethought" has been "forethought," by Gordimer in hyperperceptive mode.

This formal tension between limited and unlimited subjectivities is particularly apparent in Gordimer's less audacious presentation of July, which takes up the idea, foregrounded by the inclusion of I Promessi Sposi, of translation as metaphor and technique. July initially speaks to the Smales family in a pidgin arranged in "the servant's formula, attuned to catch the echo of the master's concern" (95): "You like to have some cup of tea?" (1). In contrast, conversations with his wife Martha are presented in a standard English that is signalled as a translation from "their language" (20), Shangaan. Elsewhere, Shangaan words and sentences are occasionally included but left untranslated, as in July's "teasing and encouraging" (141) words to the gumba-gumba man; for a non-Shangaan-speaking Anglophone reader, this reinforces a sense of otherness, even if the words are susceptible to translation and editorial glossing. ${ }^{1}$ But when tensions climax with July haranguing Maureen in the "heavy cadences" (152) of his own language, July's words are not even transcribed, making his reproach at least as inaccessible to the reader as it is to Maureen, who feels that "She understood although she knew no word. Understood everything: what he had had to be, how she had covered up to herself for him, in order for him to be her idea of him" (152). Gordimer thus "neither ignores July's story, nor presumes to tell it," but rather than it "remain[ing] inaccessible to the white imagination" (Newman 89) she refracts selected aspects of his "story" into these four linguistic dimensions of varying accessibility. Though in her epiphanic moment Maureen felt that she "understood everything," the narrative uses the language barrier to indicate the limits of empathy by implying yet withholding what lies beyond those limits. July's People thus suggests that alterity, like futurity, has ineffable limits, for July remains almost as unknowable as the post-revolutionary state is unimaginable; but it

1. The estranging effect of such moments - and hence July's otherness - is arguably diminished by Longman's educational edition, which includes English translations in the end-matter's "Glossary" (Nadine Gordimer, July's People, ed. Jennie Sidney [Harlow: Longman, 1991]). 
also implies that more futurity might enable better understanding of alterity, which it defers to a post-apartheid time. Though Gordimer criticized J.M. Coetzee's Life \& Times of Michael K (1983) - another "future history" set during an imagined South African civil war of uncertain outcome - for its protagonist's refusal of history ("The Idea"), her representational strategy here is not dissimilar to those of Coetzee, whose subalterns' opacities and silences resist white liberal desires for knowledge and self-validating reciprocity.

The famously "open" ending of July's People - in which Maureen runs away from July's village, fords a river (imaged as a baptism), and runs towards a helicopter (imaged as a rapist), not knowing "whether it holds saviours or murderers; and [...] for whom" (158) - might also be read in terms of a tension between the conceptions of subjectivity that the novel articulates and contrarily embodies. By 1994, when the revolution envisaged by July's People had been averted by the negotiated settlement that brought the ANC to power, the meaning of Maureen's flight had "become one of the standard debates of South African fiction" (Green 16). This debate had included perceptive analyses by Clingman, who considered that Maureen "is running from old structures and relationships [...] but she is also running towards her revolutionary destiny [...]. In part it is a flight from, but also it is a flight towards" (203), and by Visser, who observed that "Maureen has been overtaken by something far larger than herself" ("Beyond" 66). These analyses were to remain amongst the most-cited in post-apartheid criticism, including Ali Erritouni's materialist reading of the novel as a "dystopian critique of apartheid" and a non-prescriptive ("postmodern") projection of a redistributive "postapartheid utopia" (68). The debate as it stood in 2015 was summarized by Jackson: "Interpretations run the gamut from apocalyptic to utopian, but they generally share a sense of emergence from the paralysis of interregnum and of individualism giving way to collective implication" (68). However, building on Brendon Nicholls's suggestion that "Maureen's detachment from identity, family and community is linked to Gordimer's belief in the enlightened distance of the artist from their society" (33), the reading I am proposing shifts the emphasis away from a collective political impetus and back towards individual subjectivity and the artistic conundrums confronting the late-apartheid writer. In light of Gordimer's epistemological and ontological reflection on potential experiences and experience's potential, Maureen's action can be construed as her running towards a third phase of experience that might have the potential to make sense of the second (in July's village), just as the second proved to have the potential necessary to make sense of the first (in Johannesburg's suburbs); or, indeed, as her running away from such a limiting conception of subjectivity in which perception is contingent on position. Rather than a nebulous political prognosis, Gordimer's cliffhanger can thus be understood as a writerly projection encapsulating the central philosophical paradox of a novel that offsets a dystopian conception of subjectivity, in which experience is deterministic and even tyrannical, by warily endorsing - and, in the end, recklessly embracing - a utopian ideal of subjectivity as heuristic, in which experience has the potential to liberate.

If Gordimer's self-reflexive examination of "the transport of a novel" in terms of its imaginative engagement with alterity and futurity thus remains as unresolved as Maureen's potential physical transport by helicopter, it at least elucidates the difficult conditions under which, in late-apartheid South Africa, an author's reach might 
tentatively exceed her grasp. It also draws attention to "the transport of a novel" as a material object itself susceptible, in apartheid South Africa and beyond, to situated interpretation and retrospective reevaluation. As Andrew van der Vlies suggests in his illuminating textual-cultural history of the book's publication and reception in different editions at home and abroad, July's People is "an instantiation of the representations it so teasingly offers its readers" (118). As such, its self-reflexive examination of subjectivity, alterity, and futurity - rooted in the unresolved ambivalence about experience's potential apparent in Gordimer's nonfiction, and reflected in divergent critical assessments of the historical conditioning of her fiction - should give the reader interpretive pause.

Peter BLAIR

University of Chester

\section{Works Cited}

Barnard, Rita. Apartheid and Beyond: South African Writers and the Politics of Place. Oxford: Oxford UP, 2007.

Bazin, Nancy Topping, and Marilyn Dallman SeYMour, eds. Conversations with Nadine Gordimer. Jackson: UP of Mississippi, 1990.

Boyers, Robert, Clark Blaise, Terence Diggory, and Jordan Elgrably. "A Conversation with Nadine Gordimer." Salmagundi 62 (1984): 3-31. Bazin and Seymour 185-214.

Chapman, Michael. Southern African Literatures. London: Longman, 1996.

CuIngman, Stephen. The Novels of Nadine Gordimer: History from the Inside. Johannesburg: Ravan, 1986.

—. "Introduction." Gordimer, The Essential Gesture 1-15.

CoETZEe, J.M. Life \& Times of Michael K. London: Secker and Warburg, 1983.

Cooke, John. The Novels of Nadine Gordimer: Private Lives/Public Landscapes. Baton Rouge: Louisiana State UP, 1985.

Dimitriu, Ileana Şora. Art of Conscience: Re-reading Nadine Gordimer. Timișoara: Hestia, 2000.

Eliot, T.S. "East Coker" (1940). Collected Poems 1909-1962. London: Faber and Faber, 1974. 196-204.

Erritouni, Ali. "Apartheid Inequality and Postapartheid Utopia in Nadine Gordimer's July's People." Research in African Literatures 37.4 (Winter 2006): 68-84.

Gardner, Susan. “'A Story for This Place and Time': An Interview with Nadine Gordimer about Burger's Daughter." Kunapipi 3.2 (1981): 99-112. Bazin and Seymour 161-75.

Gordimer, Nadine. The Lying Days. 1953. Harmondsworth: Penguin, 1994.

-. A World of Strangers. 1958. Harmondsworth: Penguin, 1983.

—. "One Man Living Through It." The Classic 2.1 (1966): 11-6. Gordimer, The Essential Gesture 79-86.

—. A Guest of Honour. New York: Viking, 1970.

—. The Black Interpreters: Notes on African Writing. Johannesburg: Spro-Cas/Ravan, 1973.

-. "The Novel and the Nation in South Africa." 1961, 1973. African Writers on African Writing. Ed. G.D. Killam. London: Heinemann, 1973. 33-52.

—. The Conservationist. London: Cape, 1974.

—. "Introduction." 1975. Gordimer, No Place Like: Selected Stories. Harmondsworth: Penguin, 1978. 9-15.

—. Burger's Daughter. London: Cape, 1979.

—. "Relevance and Commitment." 1979. Gordimer, The Essential Gesture 133-43.

—. July's People. Harmondsworth: Penguin, 1981.

—. "Living in the Interregnum." New York Review of Books, 20 January 1983. Gordimer, The Essential Gesture 261-84.

—. "The Idea of Gardening: J.M. Coetzee's Life and Times of Michael K." New York Review of Books, 2 February 1984. Gordimer, Telling Times: Writing and Living, 1954-2008. London: Bloomsbury, 2010. 396-403.

-. A Sport of Nature. London: Cape, 1987.

—. The Essential Gesture: Writing, Politics and Places. Ed. Stephen Clingman. Harmondsworth: Penguin, 1988.

—. My Son's Story. London: Bloomsbury, 1990.

GraY, Stephen. "An Interview with Nadine Gordimer." Contemporary Literature 22.3 (1981): 263-71. Bazin and Seymour 176-84. 
— and Phil Du Plessis. "Writing in Africa: Nadine Gordimer Interviewed." New Nation (September 1972): 2, 3, 5. Bazin and Seymour 59-66.

Green, Michael. "Nadine Gordimer's 'Future Histories': Two Senses of an Ending.” Wasafiri: Journal of Caribbean, African, Asian, and Associated Literatures and Film 19 (Summer 1994): 14-8.

Greenstein, Susan M. "Miranda's Story: Nadine Gordimer and the Literature of Empire." Novel: A Forum on Fiction 18.3 (Spring 1985): 227-42.

Helgesson, Stefan. Transnationalism in Southern African Literature: Modernists, Realists, and the Inequality of Print Culture. New York: Routledge, 2009.

Jackson, Jeanne-Marie. South African Literature's Russian Soul. London: Bloomsbury, 2015.

Marchant, Peter, Judith Kitchen, and Stan Sanvel Rubin. "A Voice from a Troubled Land: A Conversation with Nadine Gordimer.” Ontario Review 26 (Spring-Summer 1987): 5-14. Bazin and Seymour 253-63.

Medalie, David. "Friday Updated: Robinson Crusoe as Sub-Text in Gordimer's July's People and Coetzee's Foe." Current Writing: Text and Reception in Southern Africa 9.1 (1997): 43-54.

Newman, Judie. Nadine Gordimer. London: Routledge, 1988.

Nicholls, Brendon. Nadine Gordimer's July's People. London: Routledge, 2011.

Paton, Alan. Cry, the Beloved Country: A Story of Comfort in Desolation. New York: Scribner, 1948.

Powell, Edward. "Equality or Unity? Black Consciousness, White Solidarity, and the New South Africa in Nadine Gordimer's Burger's Daughter and July's People." The Journal of Commonwealth Literature (13 February 2017): 1-18. <https://doi.org/10.1177/0021989416687349> web.

Terkel, Studs. "Nadine Gordimer." Perspectives on Ideals and the Arts 12.3 (May 1963): 42-9. Bazin and Seymour 12-32.

Titlestad, Michael, and Mike Kissack. "The Persistent Castaway in South African Writing." Postcolonial Studies 10.2 (2007): 191-218.

VAN DER Vlies, Andrew. “July's People in Context: Apartheid's Dystopias Abroad." Nicholls 115-30.

VIsser, Nicholas. "Beyond the Interregnum: A Note on the Ending of July's People." Rendering Things Visible: Essays on South African Literary Culture. Ed. Martin Trump. Johannesburg: Ravan, 1990. 61-7.

—. "The Politics of Future Projection in South African Novels." Bucknell Review 37.1 (1993): 62-82.

Wagner, Kathrin. Rereading Nadine Gordimer. Bloomington: Indiana UP, 1994.

Wright, Laura. "National Photographic: Images of Sensibility and the Nation in Margaret Atwood's Surfacing and Nadine Gordimer's July's People." Mosaic: A Journal for the Interdisciplinary Study of Literature 38.1 (2005): 75-92. 